\title{
Em movimento: trabalho em canaviais e trajetórias de trabalhadores no Triângulo Mineiro nas últimas décadas
}

\author{
Paulo Roberto de Almeida* \\ Sérgio Paulo Morais ${ }^{* *}$
}

\begin{abstract}
Resumo: Este texto aborda a temática da agroindústria na perspectiva de trabalhadores cortadores de canade-açúcar na região do Triângulo Mineiro. Explora a historicidade da luta de classes por meio da experiência no trabalho. $O$ objetivo maior é o de ressaltar determinadas relações estabelecidas entre trabalhadores e usinas, mostrando mudanças nas relações produtivas, transformações nos modos de vidas e formas de exploração dos trabalhadores. $\mathrm{O}$ artigo também discute tendências na luta pela terra, questões ambientais e introdução de máquinas no plantio e na colheita da cana.
\end{abstract}

Palavras-chave: Trabalhadores; Cana-de-açúcar; Triângulo Mineiro.

Abstract: This text is a reflection about the problematics of agrobusiness in the experience sugarcane's workers of the Triângulo Mineiro region. Exploring the historicity of the class struggle through work experience. The main objective is to study the relations between workers and relations of production, showing changes in work, changes in the lives, from the current characteristics of the exploitation of workers. The article also discusses trends in the struggle for land, environmental issues and the introduction of machinery in planting and harvesting sugar cane.

Keywords: Workers; Sugarcane; Triângulo Mineiro.

Neste país, de um modo peculiar, o interesse por "novos sujeitos" e por suas diferentes formas de organização toma significativa força acadêmica e social em anos finais e eminentemente posteriores à derrocada do regime militar. ${ }^{1}$ Ao reconhecermos as vastas dimensões tentaculares do assunto e o extenso campo de possibilidades para entendermos as razões de se buscar novos "atores", localizamo-nos entre aqueles que buscam nas complexidades do vivido a concepção materialista da história, que, a saber, "seria a produção e a reprodução da vida real" o "fator que em última instância determinaria a História". ${ }^{2}$

\footnotetext{
${ }_{* *}^{*}$ pesquisa que originou este artigo foi apoiada pela FAPEMIG - Edital Universal/2009.

** Professor Associado da Universidade Federal de Uberlândia. Atua nos programas de graduação e pósgraduação em História (INHIS), Linha Trabalho e Movimentos Sociais.

Professor Adjunto da Universidade Federal de Uberlândia. Atua nos programas de graduação e pósgraduação em História (INHIS), Linha Trabalho e Movimentos Sociais.

1 Entre outros, cf. SADER, E. Quando novos personagens entram em cena: experiências e lutas dos trabalhadores da grande São Paulo, 1970-1980. Rio de Janeiro: Paz e Terra, 1988. MUNAKATA, K. O lugar do movimento operário. In. Anais do IV Encontro Regional de História de São Paulo, ANOUH-UNESP, Araraquara, 1980, p. 61.

${ }^{2}$ Cf. ENGELS, F. Carta de Friedrich Engels a Bloch, 21-22 set. 1890. In: MARX, Karl; ENGELS, Friedrich. Obras Escolhidas. São Paulo: Alfa-Ômega, 1986. v. 3.
} 
Trataremos, neste texto, do trabalho e de trabalhadores a partir de dados, evidências e reflexões advindas de recente pesquisa sobre canavieiros da região do Triângulo Mineiro e suas relações com o Sindicato dos Trabalhadores Rurais localizado na cidade de Centralina, Minas Gerais. ${ }^{3}$

Não é nossa intenção fazer aqui um balanço de pesquisas sobre trabalhadores rurais e sindicalismo no Brasil nos últimos anos. Trataremos apenas de acompanhar como os trabalhadores, por meio de suas organizações, interpretam e enfrentam questões relativas ao trabalho e às mudanças que se avizinham em uma atividade cuja exploração sempre foi constante na história deste país.

\begin{abstract}
Pontualmente às $4 \mathrm{~h}$ e 42 minutos, a canavieira Ilma Francisca de Souza parte para o trabalho com sua marmita fornida de arroz coberto por uma lingüiça cortadinha. Em outro bairro de Serrana, ainda antes de o sol nascer, Rosimira Lopes sai para o canavial levando arroz com um só acompanhamento: feijão. Durante o dia, elas vão dar conta da comida, que já terá esfriado. A despeito do notável progresso que ergue usinas de etanol com tecnologia assombrosa, o Brasil segue sem servir refeições quentes aos lavradores da cana-de-açúcar. A bóia continua fria. [...] A riqueza do setor sucroalcooleiro, que movimentará neste ano $\mathrm{R} \$ 40$ bilhões, não atingiu os lavradores. Em 1985, um cortador em São Paulo ganhava em média R\$ 32,70 por dia (valor atualizado). Em 2007, recebeu $\mathrm{R} \$ 28,90$. A remuneração caiu, mas as exigências no trabalho aumentaram. Em 1985, o trabalhador cortava 5 toneladas diárias de cana. Na safra atual, 9,3. [...] Exige (-se) alto esforço físico uma atividade em que é preciso dar 3.792 golpes com o facão e fazer 3.994 flexões de coluna para colher 11,5 toneladas no dia. Nos últimos anos, mortes de canavieiros foram associadas ao excesso de trabalho. Conta-se a seguir o caso de um bóia-fria que morreu semanas após colher 16,5 toneladas. Não há paralelo em qualquer região com tamanho rendimento $[. ..]{ }^{4}$
\end{abstract}

Muito provavelmente, nenhuma categoria de trabalhadores seja tão ou mais reconhecida pelo grau de esforço na atividade e pelo risco de morte no trabalho como são os cortadores de cana no Brasil. Mas existem outros trabalhadores que exercem, em conjunto com os cortadores, atividades na produção de açúcar, álcool e outros produtos derivados de tal planta.

De modo amplo, entre as diversas funções e divisões, registramos a existência de "bituqueiras": mulheres que recebem diárias, não possuem carteira assinada e se ocupam do recolhimento dos talhos que se dispersaram no corte feito por máquinas; "plantadores": homens e mulheres que, como o próprio nome indica, plantam a cana, atirando "perigosamente" talhos diretamente de caminhões, equilibrando-se na própria cana, a uma altura de mais de três metros e meio, para alocá-la nas covas. Recebem por dia de trabalho e geralmente são empregados posteriormente no corte ou na aplicação de veneno; os "cortadores" propriamente ditos, que trabalham com carteira assinada e por produção, que recebem, de acordo com a safra de 2008/2009, em média, R\$ 25,00/dia; existem

\footnotetext{
${ }^{3}$ Acervo da Pesquisa Histórias, Memórias e Cidadania: Estudo Sobre os Fluxos Migratórios de Trabalhadores para o Triângulo Mineiro nas últimas décadas. Apoiada pela Fapemig (2008-2010).

${ }^{4}$ MAGALHÃES, Mário; SILVA, Joel. O submundo da cana. Folha de S. Paulo, 24/08/2008.
} 
referências, também, aos que trabalham no "combate" /veneno, que não se empregam por produção, entretanto, possuem carteira assinada.

Nas narrativas produzidas na pesquisa, em forma de entrevistas, estão presentes as diversas maneiras de organização de trabalho nos canaviais do Triângulo Mineiro. Em nossos diálogos, são expressas as formas de contratação - no geral, realizado por safra, sob a intermediação dos sindicatos; os modos utilizados para atribuir valor ao que foi realizado no dia de trabalho dos cortadores; as maneiras de realizar o corte, as utilizações de equipamentos de segurança (e as avaliações destes), as pausas regulamentares para almoço, ingestão de soros e repositores, a presença de banheiros nos ônibus que transportam os trabalhadores - circunstâncias normatizadas ${ }^{5}$ e fiscalizadas, tanto pelos sindicatos quanto pelos fiscais do Ministério do Trabalho, entre outros.

Considerando modos de vida, moradia, interpretações sobre o trabalhar/condições de vida, registram-se nas entrevistas realizadas durante a pesquisa narrativas sobre o modo de encontrar trabalho; relatos sobre as viagens; sobre a vida familiar; sobre a compra "fiada" nas mercearias; além de falas sobre aluguel, estratégias de sobrevivência (compra coletiva de alimentos, empréstimos de cartões telefônicos, organização da rotina da casa), entre outros. Assim, condições materiais de vida vão precedendo e abrindo possibilidades para as condições de trabalho.

Nessas ambiências, o termo migrante tem sido recorrente em pesquisas recentemente produzidas sobre a temática, dando-nos a oportunidade de formular, a partir delas, algumas ponderações que nos preocupam, enquanto proponentes deste artigo. ${ }^{6}$ Trata-se de um fenômeno que vem provocando transformações reais na realidade brasileira, influindo na reconstituição do terreno e da vida urbana: o processo migratório, com suas especificidades, materializa os resultados da exploração de categorias diversas e dispersas de trabalhadores, fazendo com que transitem pelo território nacional em busca de sobrevivência. Esse processo migratório precisa ser compreendido amplamente, pois não se trata apenas de movimentação territorial de trabalhadores, já que evidencia diversas contradições vividas.

Diante disso, em contraposição aos paradigmas que envolvem o termo "migração", 7 temos utilizado a ideia de um movimento transitório de trabalhadores. Pois, os trabalhadores se movem para essa região para lidar com a cana, ou com a colheita de laranja, com o reflorestamento, enfim, procuram atividades, deslocam-se pelo trabalho rural, ou mesmo urbano, com ou sem contrato regulamentado e retornam para os locais em que moram suas famílias, ou se deslocam para outros lugares, em busca de outras atividades. Seguem safras, ocupam-se de atividades diversas, movimentam-se em determinados espaços de tempo.

\footnotetext{
${ }^{5}$ Cf. CONTRATO DE SAFRA: manual. Brasília: MTE/SIT, 2002.

6 NASSER, Sérgio Daniel. "Eu vou entrar no mundo": Experiências de trabalhadores migrantes na região de Ribeirão Preto. 1980-2007. Dissertação (Mestrado em História), Programa de pós-graduação em História/INHISUFU, Uberlândia, 2008, f. 115.

${ }^{7}$ Importante discussão a respeito foi realizada por DURHAM, Eunice Ribeiro. A caminho da cidade: a vida rural e a migração para São Paulo. São Paulo: Perspectiva, 1984.
} 
Para observarmos a amplitude do problema, lidamos com a vida nas cidades; a multiplicidade de experiências nas relações sociais que envolvem, além do trabalho, a moradia, a busca de serviços públicos, a permanência de trabalhadores nos pequenos municípios; as transformações advindas da maquinização das plantações; as mudanças nas tessituras da agricultura familiar; as alterações no meio ambiente; e a noção de fim do "El Dorado" que tem se estabelecido, no período, por razão destas e de outras modificações vivenciadas.

Ao mesmo tempo, com a utilização do termo "movimentação transitória", tentamos dar conta de alterações mais amplas no processo histórico constituído nos últimos trinta anos, os quais envolvem não somente o trabalho na cana-de-açúcar ou outras atividades, com a presença de "mão de obra" de outras regiões. Pois a movimentação, por si somente, permite a precarização do trabalhador, ao colocá-lo em situações que são determinadas por "aquilo que tiver para fazer" nos lugares para onde viaja, e não por ser exímio em atividades já experimentadas. Reconhecemos obras e visões em que os trabalhadores que viajam são levados por senso de aventura da idade e etc. ${ }^{8}$ Entendemos também que muitos retornam quase anualmente para o mesmo local de anos anteriores e para as mesmas funções.

Essa concepção aparece em diversas narrativas produzidas por intermédio de nossa pesquisa. Aqui, destacamos trechos de entrevistas realizadas com Eurípedes Batista Ferreira (presidente Sindicato dos Trabalhadores Rurais de Centralina e Araporã):

Entrevistador: E esses migrantes, estão retornando ou permanecendo na região? Eurípedes: Pra te falar, a gente tem uma série de problema com esse povo, a gente já procurou, tipo assim, as prefeituras daqui [...] e outros sindicatos, nos tamos com um problema sério; quê que é problema sério? Pessoas sai lá de seu município e vem pro município tal. Ele vai cortar cana, vai plantar e vai fazer o quê, que aqui não tem. Aí, chega aqui, é um problema social pras prefeituras; eles chegam e vem e nesse período agora já tá começando quando cinquenta, sessenta, setenta pessoas chegam sem saber nada; eles vem por que aqui é bão, igual na Serra Pelada. Vem por que aqui, e chega, aqui não tem nada, não tem dinheiro pra voltar, não tem dinheiro pra... não tem lugar pra ficar. É um problema pro município, um problema pro sindicato, um problema pra própria empresa que ele veio e vai lá pra porta, então, não é uma coisa boa. [...] O município não quer nem saber de migrante; não que nem saber se tem gente aqui, se tem ser humano; se vem criança de lá... quando chega aqui - pra você ter um exemplo - tem uma dificuldade, eu mesmo aqui nesse sindicato, você leva gente pra outro município. "Ah, eu vou tirar um documento tal". O cara é lá da barra deles... e eles não atendem de jeito nenhum. Chega no posto de saúde, cada município tem $X$ vagas né? Então, tem dez vagas, vinte vagas pra um médico tal. Aí, vem cinquenta de lá, pra arrancar dente (por que lá quase num tem dentista)... aproveita e vai. Tem dez baiano na fila, e eles num atende. ${ }^{9}$

\footnotetext{
${ }^{8}$ MARTINS, José de Souza. A escravidão na sociedade contemporânea: A reprodução ampliada anômala do capital e a degradação das relações de trabalho. In: A sociedade vista do abismo: novos estudos sobre exclusão, pobreza e classes sociais. Petrópolis: Vozes. 2002, p. 151-162.

${ }^{9}$ Op. cit. Acervo da Pesquisa (2008-2010).
} 
Além do município e da falta de recursos dos que chegam, existem modos de triagem que qualificam os trabalhadores que transitam pelo país por ordem de força e de idade:

Eurípedes: [...] chega aqui e, tipo assim, pra você ter uma noção, quando vai fazer uma fichação - que a gente fala, é quando vai contratar, é outra coisa, não é! - aqui tem uma usina que é pra fichar oitenta, apareceu duzentos e cinquenta em um dia, duzentos e cinquenta senhas (tive que dar senha ainda) e os outros tão por aí. Esperando, eles pega nome de todo mundo; entrevista todo mundo. Dez dias depois, sai a lista dos oitenta e aqueles outros: sem fazer nada, sem nenhum tostão... não tem uns que tá na casa dum amigo... (o outro também já não conseguiu), Aí vem pro sindicato; vem pra prefeitura. Ai, começa a cascata. Porque... tipo, vamos dá em números procê, vem quinhentas pessoas pra cá... ficho cem, sobrou quatrocentas. Essas quatrocentas não tem nada pra voltar, a família tá lá, passando dificuldade. Ele vai fazer o quê da vida? Nós já fizemos vaca, ligamos pro prefeito da cidade lá pra mandar ônibus pra levar gente embora. Eles ficam louco aqui... uns perde a cabeça, vai bebe cachaça... uns vai robar (outros vai isso). Acontece tudo, outra coisa que nos temos um problema maior procê ver, essa é minha preocupação, e os governo não vê, na maioria dessas pessoas que é da cana, uma grande parcela tem mais de quarenta anos, quarenta, quarenta e cinco e cinquenta: usina não quer nem olhar pra esses que ta com quarenta. Eles quer cara fortão mesmo, olha assim o bicho, tá! Eles não quer gente de meia idade, essas pessoas não conseguem serviço no mercado, não tem qualificação, só tem força! Eles já tá perdendo as força, vai fazer o quê? ${ }^{10}$

As falas dos trabalhadores caracterizam a dureza de atividades, a utilização de força e a exaustão provocada pela jornada, como particularidades de se ter "couro grosso" para sua realização. ${ }^{11}$ Entre outras entrevistas, temos:

Entrevistador: O pessoal vinha pra cá, você alugava casas, tudo, o interesse do pessoal era grande grande, não?

Anilton: Lógico. Com certeza, muito grande.

Arilson: Muito grande, tem muita casa alugada aí.

Anilton: O pessoal que vem de fora, também, nordestino, num é um pessoal assim... é um pessoal que já tá acostumado com o trabalho pesado, muito mais pesado, né. Então, desenvolve o trabalho muito mais do que o pessoal da cidade.

Arilson: Aí, junta as duas coisas: um que trabalhava pesado e a necessidade, né. Aí, uma coisa leva à outra. Tem o couro grosso, né. Tá mais acostumado. ${ }^{12}$

Essas diferentes dimensões (falta de recursos, excesso de trabalhadores, escolha dos mais fortes e mais novos etc.) fazem com que a condição de estar em outra cidade, sem recursos e com a antipatia dos munícipes permita situações extremas de exploração do trabalho e mesmo de escravismo.

Registramos nossa ciência de que o trabalho análogo ao da escravidão é uma realidade presente hoje na sociedade brasileira. Muitos acadêmicos têm trabalhado com a

\footnotetext{
${ }^{10}$ Ibidem.

${ }^{11}$ Entrevista feita por Gabriel de Araújo Oliveira. Local: Campina Verde (MG). Entrevistados: Arilson Joaquim da Silva e Anilton Fernado dos Reis. Data: 16/03/2009. op. cit. Acervo da Pesquisa.(2008-2010).

12 Idem.
} 
temática $^{13}$, e ações de fiscalização e combate têm sido realizadas em diferentes regiões do país ${ }^{14}$, mas o problema tem merecido observação e interesse de movimentos organizados e setores de segurança pública.

Entre significativos acordos, firmados entre Ministério Público Federal, Ministério do Trabalho, sindicatos e empresários, estão os Contratos de Safra $(2002)^{15}$, por exemplo, realizados na tentativa de diminuir as ocorrências de escravidão. Um dos pontos desse significativo documento, baseado no Código Penal Brasileiro, e não somente na legislação trabalhista, diz respeito ao espaço de moradia dos trabalhadores, ressaltando ser "aconselhável" o recrutamento de "mão de obra" nas proximidades do local de trabalho.

Por um lado, essa relação trabalho/escravo, ou trabalhador/escravidão, retoma a memória de certa condição histórica vivida por milhares de canavieiros na região Nordeste do país, nos séculos XVI e XVII, nos quais foram utilizados trabalhadores cativos para alimentar a indústria e o significativo comércio de açúcar na Europa. Por outro, indica condições degradantes de trabalho na atualidade. O jornal Folha de S. Paulo, em texto anteriormente citado, indica uma relação entre os dois "períodos":

No auge e na decadência do ciclo da cana-de-açúcar, os escravos cuidaram da lavoura e puseram os engenhos para funcionar. A arrancada do etanol brasileiro foi dada por lavradores na maioria negros. Assim como os escravos sumiram de certa historiografia, os cortadores são uma espécie invisível nas publicações do setor. Exibem-se usinas high-tech, mas oculta-se a mão-de-obra da roça. Impressiona na viagem ao mundo e ao submundo da cana a semelhança de símbolos da lavoura atual com a era pré-abolição. $O$ fiscal das usinas é chamado de feitor. Acumulam-se denúncias de trabalho escravo. É um erro supor que as acusações de degradação passem longe do estado mais rico do país e se limitem ao "Brasil profundo". Uma delas é narrada adiante. Em São Paulo, localiza-se Ribeirão Preto, centro canavieiro tratado como a nossa "Califórnia". ${ }^{16}$

Relatos sobre escravidão, contidos nessa reportagem e em outras fontes, traçam uma perspectiva que se coaduna à morte, à exploração do trabalho, entre outros. De certo modo, esse é um dos pontos em que o elo da escravidão/movimentação de trabalhadores ocorre com mais frequência, pois, grosso modo, o trabalhador torna-se (em diferentes circunstâncias) um "devedor" de transporte, moradia, alimentação, medicamentos etc., enquanto trabalhe em um local distante daquele em que vivem os familiares.

A nosso ver, nem toda a situação vivida pelos cortadores de cana está dentro do rol da "escravidão" ou de situação análoga, mas indicamos que a atividade tem potencialidade

\footnotetext{
13 Ver, por exemplo, op. cit., MARTINS, José de Souza. Vozes. 2002, p. 151-162. Disponível em: <http://www.revistasusp.sibi.usp.br/scielo.php?script=sci_arttext\&pid=S003483091989000100008\&lng=pt\&nr m=iso>. Acesso em 21/12/2010. MARTINS, J. S. Fronteira. A degradação do outro nos confins do humano. São Paulo: Hucitec, 1997.

${ }^{14}$ BARELLI, W e VILELA, R. Trabalho escravo no Brasil: depoimento de Walter Barelli e Ruth Vilela. Estudos Avançados, v. 14, n. 38. Abril, 2000. Disponível em:

<http://www.scielo.br/scielo.php?script=sci_arttext\&pid=S010340142000000100002\&lng=en\&nrm=iso>.

Acessado em 09/12/ 2009. COSTA, P. T. M. Combatendo o trabalho escravo contemporâneo: o exemplo do Brasil. Escritório da OIT Brasil/Satellite Gráfica e Editora Ltda, Brasília, 2010.

${ }^{15}$ CONTRATO DE SAFRA, op. cit.

${ }^{16}$ MAGALHÃES, op. cit.
} 
para criar explorações particulares, nas quais a vida e a liberdade dos trabalhadores correm risco de cerceamentos. A partir da existência de situações reais, entendemos que é esse um desafio e um ponto importante na pesquisa sobre tais trabalhadores, sobre suas resistências, modos de organização e sobre mudanças nas relações de trabalho.

$\mathrm{Em}$ aspectos anteriormente citados, outro significativo ponto para análise sobre o movimento realizado pelos trabalhadores já aparece desde os anos 1990: a crise em relação à cana.

Eurípedes: É, a gente vê o seguinte, no início é como um casamento, tudo foi maravilhoso no início dos anos oitenta, é... foi muito bom, por exemplo, principalmente pros migrantes, pro pessoal da região, quando chegou a cana chegou-se a coisa do futuro pra se ganhar dinheiro, chegou-se pra assim ...tudo então, todo mundo começou a... no início, procê ter uma noção, pessoas jovens que estavam estudando foi trabalhar na cana... crianças! Até que na época, naquela, tinha até criança, até que foi nosso (...era uma bandeira de luta nossa não ter menor trabalhando), tudo foi maravilhoso nos anos oitenta, mas a partir daí, eu creio que hoje, eu já vou pular pros dias de hoje, hoje nós estamos é com problema, o setor tá... parou de ganhar milhões de dinheiro, e os trabalhadores tão aí, a Deus dará. A Deus dará, por quê? A mecanização chegou, e o governo, as empresas, não tem nenhuma... não se importou com eles. Não criou nem um mecanismo, nenhuma questão mais social (na área social) pra esses trabalhadores. Então acho que eles só sabe cortar cana; só sabe plantar cana; só sabe capinar. Uma grande maioria de dez, quinze anos pra cá, só sabe mexe com isso. Não sabe mexer com outra coisa, e agora, a cana tá sumindo. ${ }^{17}$

Diferentemente da década de 1980, época de um "El Dorado", em anos posteriores, a cana não mais foi vista como um produto de geração certa de renda, pelo menos, aos trabalhadores. Não nos aprofundaremos aqui nessa perspectiva, um tanto paradoxal, já que, com a recente configuração internacional de um comércio de bicombustíveis, a ideia parece um tanto fora do lugar. Como elemento de trabalho, ou dizendo de outro modo, como forma de subsistência e de manutenção da família (em outro estado), a cana tem se tornado um elemento incerto e, por vezes, raro para os trabalhadores.

As significativas entrevistas realizadas com o presidente do Sindicato dos Trabalhadores Rurais nos relevam traços do que chamamos de crise, na perspectiva do trabalho e dos trabalhadores. Por um lado, em tais narrativas, percebem-se dinâmicas que se distanciam e se integram à tão propalada crise mundial 2008-2009. Mas por outro, as avaliações do narrador desvendam profundas rupturas nas atividades de trabalho nos canaviais, advindas com a precarização promovida pela mecanização do corte e a diminuição de oportunidades de trabalho camponês, em razão da presença hegemônica da plantação de cana, da diminuição dos espaços possíveis para a agricultura familiar, entre outras.

Afere-se também nestas entrevistas uma mudança significativa dos recursos ambientais da região do Triângulo Mineiro, principalmente no que se refere às nascentes dos rios, diminuição na produtividade das terras etc. Interessante notar, nas perspectivas

\footnotetext{
${ }^{17}$ op. cit. Acervo da Pesquisa (2008-2010).
} 


\title{
apontadas pelo narrador, que as "queimadas" feitas para facilitar o corte manual da cana são vistas como "mal menor" no processo de degradação ambiental:
}

\begin{abstract}
Entrevistador: Agora, você acha que isso tem relação com aquela discussão que foi feita no Triângulo, da autorização pra implantação das usinas, mas ao mesmo tempo, a proibição das queimadas?

Eurípedes: Com certeza... eu vou falar uma coisa aqui, que as vez vão me massacrar por isso, não é? Eu defendo o meio ambiente, acho que tem tudo há ver. Mas as queimadas não é o mais importante na cana de açúcar. Não é o problema principal da cana de açúcar... Enquanto eles tão vendo assim, não se pode queimar... por que...? Mas aí eles pega e me dá outorga pra sugar os rios... sugar as águas... isso vai depredar mais o meio ambiente. Eles pegam, jogam agrotóxico... de tudo quanto é tipo nas lavouras, nas nascentes... e eles não falam isso. Os promotores é... fala: "vamos proibir as outorgas", "vamos cortar as águas"..., "não usar tipo X de herbicida"... mas eles proibiram as queimadas, que reflete na questão social... tem $X$ pessoas que dependem dessa queimada, é um problema do meio ambiente, é, mas tem outros que eles não olham... não é o problema principal do meio ambiente essas queimadas na cana não tem outras coisa que prejudicam muito mais. $^{18}$
\end{abstract}

Tal como ocorrido em outros estados, Minas Gerais tem implantando medidas para a proibição de queimada da cana ${ }^{19}$ e para a concomitante efetivação de máquina de corte. Ainda controversos, o fim das queimas e o pacto pela maquinaria perpassam temáticas ambientais e até mesmo questões de produtividade, tal como indica o Protocolo Mineiro:

\begin{abstract}
Minas Gerais já conta com novas regras para a colheita de cana-de-açúcar. A partir deste ano, empreendedores do setor sucroalcooleiro devem iniciar a substituição da queima da cana, utilizada para evitar o risco de cortes do trabalhador com a palha, pela mecanização da colheita. A medida, assegurada com a assinatura do Protocolo de Intenções de Eliminação da Queima da Cana no Setor Sucroalcooleiro, implica em ganhos ambientais, como a redução da emissão de dióxido de carbono (CO2), incentivo ao uso da palha da cana para produção de energia e o desenvolvimento sustentável do setor sucroalcooleiro. [...] "A elaboração do protocolo durou um ano. Todas as partes envolvidas tiveram que ceder em alguns pontos, para um consenso final de que não podemos mais queimar a cana e contribuir para a emissão de CO2", declara o presidente do Sindicato da Indústria de Fabricação do Álcool no Estado de Minas Gerais e Sindicato da Indústria do Açúcar no Estado de Minas Gerais Siamig/Sindaçúcar, Luiz Custódio Cotta. Ele destaca a possibilidade de destinação da palha para geração de energia. "Com a utilização de $50 \%$ da palha da cana, que não mais será queimada, o setor poderá
\end{abstract}

\footnotetext{
${ }^{18}$ Eurípedes Batista Ferreira (Baianinho) trabalhou como agricultor desde muito jovem, e é o atual Presidente de Sindicato dos Trabalhadores Rurais de Centralina e Araporã. ALMEIDA P. R. RESENDE, R. C., MORAIS, S. P. Apresentação - Transformações sociais e questões ambientais na região do Triângulo Mineiro. Entrevista com Eurípedes Batista Ferreira Presidente do Sindicato dos Trabalhadores Rurais e Agricultores Familiares de Centralina e Araporã. Disponível em:

<http://www.historiaperspectivas.inhis.ufu.br/viewarticle.php?id=244\&layout=abstract>.

${ }^{19}$ Indicamos a existência do Decreto Federal de número 2.661 de julho de 1998 , que determina a eliminação da queima da cana no ano de 2018, entretanto, legisladores estaduais têm indicado datas anteriores para a eliminação da prática, que amplia enormemente a produção do corte manual. Minas Gerais, enfatizando a mecanização da lavoura, indica como data terminal para as queimadas o ano de 2014. Cf. Protocolo que regulamenta queimadas. Disponível em: <http://www.agricultura.mg.gov.br/noticias/719>. Acesso em $21 / 03 / 2012$.
} 
gerar 587 megawatts de energia, uma potência bem acima da barragem de Três Marias".

A palha gerará energia, enquanto os trabalhadores:

Com a mecanização, a máquina colhedora de cana realizará o trabalho de cerca de oitenta pessoas. Com isso, os trabalhadores que não serão aproveitados deverão ser qualificados para assumirem novos postos de trabalho. Vários empreendimentos do setor já deram início à requalificação e planejam o aproveitamento dessa mão-de-obra em outros setores. $O$ incentivo aos cursos de capacitação e requalificação da mão-de-obra que trabalha nas lavouras de cana, por parte do poder público e do setor privado, é uma exigência do protocolo. Uma das estratégias previstas no documento é a intensificação de políticas públicas de incentivo à agricultura familiar. A fiscalização do cumprimento do protocolo ficará a cargo do Sistema de Meio Ambiente (Sisema). De acordo com o presidente do Conselho de Administração do Grupo Moema, Maurílio Biagi, as duas usinas que o grupo paulista possui nas cidades de Itapagipe e Frutal, no Triângulo Mineiro, já têm $70 \%$ da produção mecanizada. "Estamos investindo na requalificação dos trabalhadores, dando educação e instrução". As duas indústrias empregam 4 mil pessoas no parque industrial e na área de lavoura. ${ }^{20}$

Alguns sindicatos e sindicalistas, entretanto, aparentavam tranquilidade em relação à implementação de máquinas, indicando a permanência de trabalhadores no corte e/ou em atividades outras. Perspectiva semelhante pode ser aferida na entrevista realizada com a presidente do Sindicato dos Trabalhadores Rurais de Santa Juliana, Lílian Bernardes da Silva, em maio de 2009.

Entrevistador: Em relação às maquinas, o que você percebe?

Lílian B.: Não, eu acho que os trabalhadores já estão começando a pensar que pode acontecer de eles ficar sem o serviço. Por que aqui na nossa região, é uma região que tem muita atividade. Igual eu te falei, tem atividade aí no hortifrutigranjeiro, aqui dentro da cidade tem muito leite, tem muita plantação de soja, de outros cultivos. Mas eu acho que a maior preocupação não é só aqui... é geral, é em outros estados (também), Minas e em vários estados. Porque é difícil se pensar que pode chegar o maquinário e pode ficar todo mundo sem emprego, num tem outra maneira de ver isso. Eu acho assim, que isso pode gerar um certo medo de ficar sem emprego. Só que aqui, esse assunto ainda num foi assim... Aqui em Santa Juliana, ainda num chegou! Porque quando isso acontecer, (que vai mecanizar e tal) eles [usineiros] passa tudo pra gente [para o sindicato], né? Aqui tem probabilidade, mas ainda num foi nada... e eu acho também que toda parte que é mecanizada, até o meu conhecimento, tem que ter tantas partes de trabalhador manual. Isso conforme a CLT, conforme a [?], é cinquenta por cento. E eu num sei se isso vai ser alterado, a gente ainda num sabe. Até agora, nem pra mim, nem pra nenhum sindicato aqui da região foi passado essa alteração. Então, da mesma forma que existe maquinário, pra gente ainda existe corte manual.

Entrevistador: Mas eles [os trabalhadores] reclamam muito? Por que eles estão sentido que as máquinas chegarão e que não haverá mais queimadas?

${ }^{20}$ Cf.: <http://www.agricultura.mg.gov.br/noticias/719, acessado em 21/03/2012>. 
Lílian B: Não, é isso que eu tô te falando. Desde que tem a Usina, isso vai... das variações que são plantadas. Isso num é que tem que queimar todas, nem todas são queimadas. [...] Não, ainda não tem essa lei qui proíbe. ${ }^{21}$

Tal ponto de vista, em 2009, não era comum a outros sindicatos da região, como discutiremos posteriormente. Porém, mesmo com resoluções e legislações formuladas, o assunto da máquina no corte da cana foi tratado com muita obscuridade. Caminhando por vias ambientais e/ou por vias de produtividade, a máquina interferiria em uma etapa na qual se assentavam (e ainda se assenta) milhares e milhares de trabalhadores, que se movimentavam para a região e sobreviviam nela de modo precário.

A existência de máquina específica para a colheita da cana-de-açúcar não é recente. As primeiras máquinas que chegaram ao Brasil datam dos anos 1950; a primeira colhedeira automotriz de fabricação brasileira (Sucreris) foi posta em operação na safra de 1956/57, mesma época em que se produzia uma segunda marca de colhedeiras no país (Empresa Motocana). Nos anos 1970, predominou no mercado a máquina colhedora tipo chopper, da marca Santal/AS. ${ }^{22}$ De certa forma, o trabalho manual se sobrepujou à utilização de máquinas até os dias atuais; o que temos, então, de novo nas perspectivas apresentadas? Ou, de outra maneira: o combate à escravidão, a elaboração de acordos de safra e de queimadas - que objetivam gerar melhorias ambientais - e a pretensa qualificação dos trabalhadores têm mudado significativamente a lida nos canaviais e o perfil dos cortadores de cana? Tais transformações foram originadas por razão da força e coesão dos trabalhadores, dos sindicatos e de movimentos sociais inerentes à estrutura agrária nacional, ou são simples reajustes nos modos de produção e industrialização de álcool, açúcar e outros produtos da cana?

É preciso, antes de tudo, salientar que consideramos importantes para o debate obras que lidam com as modificações nas atividades no campo pela ótica da "reestruturação produtiva" e seus impactos. Mas tais estudos centralizam, a nosso ver, a discussão no trabalho e, ao mesmo tempo, tendem a indicar um enfraquecimento dos trabalhadores frente às transformações apresentadas pelos industriais agrícolas. ${ }^{23}$

\footnotetext{
${ }^{21}$ Entrevista feita por Marco Túlio Melo Morais. Local: Santa Juliana (MG). Entrevistada: Lilian Bernardes da Silva (presidente do sindicato de Santa Juliana). Data: 18/05/2009. op. cit. Acervo da Pesquisa.(2008-2010).

${ }^{22}$ Para outras e atualizadas informações sobre colhedeiras de cana-de-açúcar, ver NEVES, Jorge Luís Mangoline. Avaliação de perdas invisíveis em colhedoras de cana-de-açúcar picada e alternativas para sua redução. Tese (Doutorado em Engenharia Agrícola), Universidade Estadual de Campinas, Campinas, 2003. f. 223.

${ }^{23}$ Entre diferentes autores e obras, Cf. ALVES, F.; ASSUNÇÃO, M. R. Reestruturação e desregulamentação do complexo sucroalcooleiro: disfunções e propostas de políticas públicas. In: PAULILLO, F; ALVES, Francisco (orgs.). Reestruturação agroindustrial: políticas e segurança alimentar regional.. São Carlos: EdUFSCar, 2002, p. 109-.151. AZEVEDO, J. R. N; THOMAZ JR., A.; OLIVEIRA, A. M. S. A nova ofensiva do capital canavieiro e os desdobramentos para o trabalho no Pontal do Paranapanema e Alta Paulista (SP). Geografia em Atos, n. 6, Volume 1, Presidente Prudente, Dezembro de 2006, p. 3-10. THOMAZ JR., A. Gestão e ordenamento territorial da relação capital-trabalho na agroindústria sucroalcooleira. Informações Econômicas, São Paulo, v. 30, n. 4, abr. 2000. . Por trás dos canaviais: os nós da cana. São Paulo: Annablume, 2002. ; OLIVEIRA, A. M. S. (org.); GONÇALVES, M. A. (Org.). Geografia e trabalho no século XXI. Vol. 3. Presidente Prudente: Editorial Centelha, 2007.
} 
Ao contrário das prostrações frente às inovações tecnológicas, comprova-se um significativo número de paralisações de atividades, ocupações de rodovias da região e a organização de greves; de acordo com levantamento apresentado por outros pesquisadores:

\begin{abstract}
Verificou-se nas áreas de pesquisas do Triângulo Mineiro que ocorreram greves nos anos de 2003, 2004, 2005, 2006, 2008, pautadas principalmente no reajuste do piso salarial, que atualmente corresponde a $\mathrm{R} \$ 690,00$, um dos maiores do setor na região do Triângulo Mineiro. Os trabalhadores conseguiram o fim do sistema cinco por um, com um princípio de banco de horas que transformava o domingo em dia útil de trabalho. Além disso, obtiveram a garantia da estabilidade de 45 dias, a oportunidade de conferir a pesagem da cana, a correção das precariedades de seu meio transporte e a segurança de que, na ocasião de ausência do trabalhador por motivo de saúde, o mesmo deverá receber seu pagamento pela média diária de produção e não pelo preço mínimo. Aliadas as estas conquistas, os trabalhadores garantiram por meio de negociações, o direito de não serem descontados os dias de paralisação, como apoio do Sindicato dos Trabalhadores Rurais, da CONLUTAS Regional Triângulo Mineiro e Federação dos Trabalhadores na Agricultura do Estado de Minas Gerais - FETAEMG. ${ }^{24}$
\end{abstract}

Essas manifestações indicam a força dos trabalhadores em meio às adversidades as quais temos apontado. A mecanização nas lavouras canavieiras, em tese, poderia enfraquecer as greves, praticamente anuais. De certa forma, acordos e discursos sobre a implementação da maquinaria revelam um dado: a baixa ou inexistente qualificação para o trabalho. Logicamente, há uma séria conotação de classes que culpa o trabalhador pelas mazelas de suas relações de trabalho. Na lógica da situação, ter "couro grosso" e aguentar as durezas da atividade demonstram um despreparo escolar e instrumental para funções e ocupações menos pesadas. A tensão em torno de tal perspectiva pode ser percebida nas entrelinhas de entrevistas. Na ocasião aqui assinalada, um graduando/bolsista do projeto pergunta ao trabalhador sobre como encontrar uma terceira pessoa, a qual seria posteriormente entrevistada:

Entrevistador: O senhor João, ele chega por volta de quatro e meia?

Antônio: É, ele está no serviço ainda. Só que ele é bem mais novo do que eu; ele deve ter um ano e um mês (por aí...), entendeu?

Entrevistador: Ele já trabalhou em outros lugares?

Antônio: É, nas fazendas, não é? Ele trabalhou nas fazendas... então, ele é uma pessoa do ramo, cê entendeu? Porque a pessoa para aguentar esse tipo de serviço... ela tem que ser do ramo, senão num aguenta. Comparação: se você colocar um universitário pra trabalhar na usina... 'vixi', ele vai lá uns dois, três dias... e num volta mais (ri brevemente). Igual, ele já é acostumado, não é!? Sempre na fazenda. O serviço é quase o mesmo. Então, acostuma com o serviço. ${ }^{25}$

\footnotetext{
${ }^{24}$ SOUZA, A. G.; CLEPS JR., J. O desenvolvimento da agroindústria canavieira no Triângulo Mineiro e seus impactos sobre a mão-de-obra e a produção de alimentos. In: Anais do XIX Encontro Nacional de Geografia Agrária, São Paulo, 2009, p. 1-16. Apud CLEPS JR., J. Concentração de poder no agronegócio e (des)territorialização: os impactos da expansão recente do capital sucroalcooleiro no Triângulo Mineiro. Caminhos de Geografia, Uberlândia, v. 10, n. 31, p. 249-264, set/2009.

${ }^{25}$ Entrevista feita por Gabriel de Araújo Oliveira. Local / Cidade: Campina Verde / MG. Entrevistado: Antônio Nascimento Moraes. Data: 16/03/2009. op. cit. Acervo da Pesquisa (2008-2010).
} 
Esse ponto da transformação mostra indícios de outra peculiaridade atribuída aos trabalhadores, ou mais um "prisma" em nossa discussão: a lógica do embate, da organização e do enfrentamento direto ou, mais precisamente, a desorganização e a negativa de ações "políticas" por parte desses trabalhadores "em movimento". Nesse sentindo, além do fardo do pouco estudo, da propensão à violência (pela falta de ocupações no Triângulo Mineiro), imputam-Ihes as crenças de ingenuidade, fraqueza e "alienação":

Entrevistador: $E$ como é que os trabalhadores tão vendo isso [crise da cana/diminuição do corte]? Como eles chegam e discutem isso com o sindicato? Eles fazem isso?

Eurípides: Fazem, é... até fazem. E até tem medo de fazer. Até tem medo de fazer. O cara chega... ele quer é fichar. Ah... ah, tem uns que ficha escondido, no (...eu vou trabalhar, pelo amor de Deus)... vai lá na casa do gato (o gato é o aliciador), vai no aliciador e: "pelo amor de Deus, leva eu". Então, não tá tendo nem como você chegar para chamar pra discutir. "Ih gente, vamos"!? "Amanhã nós vamos discutir isso!" Nós num temos nem muito recurso... tem que usar de todo artifício pra...Mas eles não tão aderindo, a nada! Porque os cara põe eles na corda bamba, (não tem como ele)... a gente pressionar pra se negociar, mas... ${ }^{26}$

Considerando os fatores aqui elencados e retomando a "lógica histórica"27 e o início do livro III de A formação da classe operária, de E. P. Thompson, ${ }^{28}$ faz-se necessária uma "análise válida, teórica e classista" dessa lógica, circunstanciada na vida e trabalho de tais sujeitos. "É quase impossível apresentar um relato histórico coeso sobre uma presença não coesa, (como os diversos trabalhadores que 'flutuam' numericamente nesta região)", mas é preciso tentá-lo. ${ }^{29}$

A pesquisa não alargou campos nos quais pudéssemos encontrar esses trabalhadores, em movimentos articulados ou situações de cunho político e sindical, que ultrapassassem as manifestações e greve por pagamento salarial. Entretanto, algumas evidências nos permitem traçar ou propor apontamentos para futuras pesquisas; ao mesmo tempo, nos fazem apresentar com maior rigor as dimensões e condições de classe vividas por esses sujeitos. Reservamo-nos a tarefa de alinhavar a discussão dentro das concepções sobre as quais temos insistido, a saber, o materialismo histórico e as dimensões de luta de classes apontadas em obras de historiadores militantes, como o já citado E. P. Thompson.

Vale lembrar que muitos trabalhadores que migram firmam contratos e se orientam em favor de seus direitos a partir de sindicatos. Desse modo, os sindicatos tornam-se importantes elementos nas relações e contratos entre trabalhadores e usinas. Os

\footnotetext{
${ }^{26}$ Eurípedes Batista Ferreira (Baianinho) trabalhou como agricultor desde muito jovem, e é o atual Presidente de Sindicato dos Trabalhadores Rurais de Centralina e Araporã. ALMEIDA P. R. RESENDE, R. C., MORAIS, S. P. Apresentação - Transformações sociais e questões ambientais na região do Triângulo Mineiro. Entrevista com Eurípedes Batista Ferreira Presidente do Sindicato dos Trabalhadores Rurais e Agricultores Familiares de Centralina e Araporã. Disponível em: <http://www.historiaperspectivas.inhis.ufu.br/viewarticle.php?id=244\&layout=abstract>. ${ }^{27}$ THOMPSON, E P. A miséria da teoria: ou um planetário de erros. Rio de Janeiro: Zahar, 1978.

28 2002 . A formação da classe operária inglesa: a força dos trabalhadores. v. 3. Rio de Janeiro: Paz e Terra, 29 Exterminismo e Guerra Fria. São Paulo: Editora Brasiliense, 1985, p.15.
} 
trabalhadores, por outro lado, não se restringem às delimitações dos contratos, em diferentes situações, agindo para além dos sindicatos; indicativos sobre muitas greves mostram isso. ${ }^{30}$ Importante notar, para além da sindicalização - já que o fato sindical, tal como dissemos, é para muitos trabalhadores a possibilidade de regulamentar os contratos de trabalho -, as percepções até aqui indiciadas por Eurípides Batista Ferreira, presidente do sindicato. Trabalhador rural na infância e cortador de cana na adolescência, Eurípedes percebe e narra a situação para além das relações cotidianas. Mesmo indicando e cobrando dos trabalhadores a utilização correta de EPI (Equipamentos de Proteção Individual) e das contratantes, soro, banheiro nos ônibus, água e respeito ao horário de refeição, ${ }^{31}$ as leituras e interpretações que faz partem dos modos de vida e condições de classe dos trabalhadores.

Assim, sobre a diminuição de áreas de pequena plantação, a diminuição das oportunidades de venda de alimentos em feiras:

Eurípedes: Bem, na minha região, é o seguinte: nos anos oitenta é... havia uma monocultura, que a gente falava, tinha muitas lavouras de milho, muitas lavouras de algodão, muitas lavouras de arroz tinha muitas, tinha muitos agricultores familiares. Aqui, morava muita gente nas roças (uma grande maioria morava). Mas aí, chegou a cana, chegou a cana e isso foi sumindo. Então, foi engolindo, tipo assim: uma fazenda que tinha cinquenta alqueires, ela tinha cinco pessoas morando. A usina alugou e plantou cana, até lá onde tinha a casa do cara. Aquelas pessoas veio pra cidade; elas faz o quê? Se ela plantava lá um... trabalhava pra um fazendeiro, no fundo, tinha uma horta, criava galinha e tal. Chegou a cana e trouxe um aperto aí muito grande. A grande maioria já veio pra cidade. Então, veio pra fazer o que? Na época, tinha muita... plantava-se milho, arroz, feijão, criava galinha, trazia porco pra vender na feira. Hoje até não tem mais a feira aqui. Numa cidade pequena (aqui, se você for na feira) ninguém vende galinha, por que, aonde? Então, a usina veio e abafou o município. Tipo assim, alugou os municípios. Então secou, fechou... ${ }^{32}$

Sobre os arrendamentos:

Eurípedes: [...] oitenta a noventa por cento é arrendado aqui na minha região, é arrendado. A usina tem pouca... a própria usina... em si mesmo, tem pouca lavoura. Então, alugou por dez anos aquelas pequenas propriedades que tinha vinte alqueires; alugou por dez anos; o outro tem dez alqueires, alugou por dez anos; o outro, tem cinco alqueires, alugou por dez anos. [...] O pequeno proprietário, hoje nós não temos pequeno mais. O pequeno tá aqui na cidade (ele está aposentado; quem trabalhava, aposentou e fico só na praça)... ele alugou a terra dele e tá só na praça; não está fazendo nada. Então, a usina monopolizou, ela é dona de tudo. Praticamente é a prefeita, delegada, juíza do município... ${ }^{33}$

As questões ambientais (que sempre estiveram presentes nas falas do sindicalista):

\footnotetext{
30 Entre diferentes exemplos, temos: <http://oglobo.globo.com/pais/mat/2007/06/14/296174680.asp>, pesquisado 07/09/2010; <ttp://www.midiaindependente.org/pt/blue/2008/11/432945.shtml>. Acessados em 09/09/2010.

${ }^{31}$ Tal como presenciamos em visita a canaviais.

32 Entrevista com Eurípedes Batista Ferreira; ALMEIDA P. R. RESENDE, R. C., MORAIS, S. P. Apresentação Transformações sociais e questões ambientais na região do Triângulo Mineiro.

33 Ibidem.
} 
Eurípedes: até onde eu sei, até onde, mas isso eu não sei (pela ignorância), qual é o fator que traz pra camada de ozônio... que traz pro país... que traz uma série de coisas, mas eu acho que não é tanto. Tipo assim, ou eu corto um braço, ou eu corto uma perna, né? Ou, aliás, eu corto um braço ou corto um dedo, né? Ou corto o dedo... né? Pelo menos, não dá tanto assim... quando nós queimamos ou quando nós fazemos outras coisas. Então, se nós temos que se queimar dá $X$ de impacto, se jogar herbicida, dá mais $X$, se jogar, se nós fazer irrigação... não sei se já viram, pega a água nesses corguim (sai jogando, sugando os corguim) e aguando. Toda a cana do município é irrigada... se nós irrigamos as águas, nós vamos matar todos peixe. Então, $X$ mais $X$ mais $X$ vai dar... então, se nós ("ah vamo deixar pelo menos as queimadas"), pois, se nós tira as queimadas e deixa o resto, nós perdemos $X$ com X...Então, vamos deixar queimadas e tiramos o resto, por que? Porque tirando

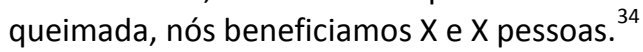

\section{O destino dos trabalhadores frente a perspectiva de ganho do agronegócio:}

Eurípedes: É... não é que a cana tá em crise. Eu acho o seguinte: muita gente tá ganhando dinheiro com a crise. Nós fizemos até um adesivo: "eles tão ganhando dinheiro com a crise". A palavra crise (agora acho que tá todo mundo usando). Eu acho que investiram. Plantaram, alugaram, tem gente que... montaram usina em cima da outra... e aqui procê ter uma região... aqui na nossa região, tem... cê sai de usina, entra em outra. Então, alguma vai ter que falir. Se nós monta dez lojinha de roupa na mesma rua... umas vai ter que falir. Se nós bota só cinco, vai funcionar... Então, não é que tá em crise. Foram desordenados. A concorrência deles mesmo é desleal [...]. Montou-se muita usina; criou-se muita expectativa e trouxe muita gente... e agora, algumas faliram, não é? Que tá em crise, não! Que álcool, todo mundo gasta; açúcar gasta, isso não para. E eles tão produzindo e plantando e alugando. Não tem crise não! A crise é dos trabalhadores; por que? Se pegava mil, agora, uma colhedeira colhe... com setenta, ficou eles que vão ganha mais dinheiro, mas a minha preocupação maior não é com a usina; com a crise, não! É com as pessoas nos temos, aqui tinha setenta mil pessoas, agora nós temos trinta mil pessoas esse ano; nós vai fazer o quê? ${ }^{35}$

Há, certamente, entendimentos amplos em torno do sindicalismo no Brasil, com estudos que mostram, por exemplo, como a legislação trabalhista (criada na Era Vargas) limita e harmoniza a própria ação sindical, constituindo um modelo limitado de sindicalismo no Brasil. ${ }^{36}$ Entretanto, as questões acima citadas e, principalmente, o modo como os problemas são interpretados, nos instigam a lidar com a situação de outro modo, buscando as dimensões e motivações políticas trazidas e elaboradas em função da diminuição do trabalho na reunião e a mudança da estrutura agrária.

A supressão da pequena propriedade; a perda do "El Dorado da cana", quando os da cidade, que esperavam lucrar com a vinda dos trabalhadores - aluguel, alimentação, lavanderia (muitos fizeram isso) -, passaram a trabalhar na lavoura de um modo mais precário, sem carteira assinada e recebendo diárias; a introdução de máquinas em etapas

\footnotetext{
${ }^{34}$ Ibidem.

${ }^{35}$ Ibidem.

${ }^{36}$ Cf., entre outros, CARDOSO, Adalberto M. A Década Neoliberal e a crise dos sindicatos no Brasil. São Paulo: Boitempo Editorial, 2003.
} 
nas quais o trabalho braçal era altamente requerido; tudo isso é interpretado como elementos latentes de uma crise.

Essas informam experiências sociais que não se limitaram a comportamentos de resignação. A entrevista com Divina Catarina Borges de Almeida, presidente do Sindicato dos Trabalhadores Rurais de Campina Verde, realizada em junho de 2009, nos alertou para dimensões outras do conflito na região, no qual trabalhadores do corte de cana agiram (e agem) como sujeitos que não apenas "migraram" ou que se submeteram a "gatos" nem disputaram entre si o ganho por produção.

A presidente nos falou de luta e busca pela terra:

\begin{abstract}
Entrevistador: E qual é a demanda que vocês têm aqui, do pessoal, qual é o trabalho que vocês exercem aqui, em geral?

Divina: Olha, pra te falar a verdade, aqui nós mexemos com todas as áreas. Sendo trabalhador rural, todas. Nós participamos da área de saúde e de tudo. Reforma agrária, é trabalho de usina, trabalho de pessoas que vêm de fora, trabalho de pessoas daqui mesmo, então, é assim, uma coisa conjunta, aqui não tem... só trabalho urbano que nós não mexemos. Com esse, nós não temos contato, tem alguma informação que a gente passa, mas esse não é o nosso serviço. Nosso serviço é com o trabalhador rural, com o pequeno proprietário rural, também né, que é do campo e também mais voltado aos assentamentos e à usina. [...] [Os que vêm para trabalhar com a cana] uns voltam, outros ficam por aqui, já se empregam por aí em outra fazenda, cê entendeu? Uns arrumam uma agregação por aqui mesmo, ou seja, constitui família, isso aconteceu muito, né. Tem gente aqui que era, veio de... dessas cidades do norte aí, já tem pedaço de terra aqui de assentamento, tem família, cê entendeu? Então, tudo isso acontece. Tem três anos e pouco que essa empresa está aqui, né. Mas, acho que entre aquele relacionamento de amigos ali, de um e de outra, até constituir família mesmo. Porque tem gente que agora, é morador ou aqui, ou na fazenda. Então, eles ambientam rápido. Muitos não, voltam pra trás. Muitos decepcionados, às vezes, não é? Por que, como que faz, às vezes, num é aquilo que eles esperavam, uns voltam pra trás outros não, já ficam, criam um ambiente por aqui mesmo e já vão ficar e lutar por aqui mesmo. [...] Em assentamento também. Muitos aqui, por exemplo, têm a [nome do assentamento não legível], que a maioria do pessoal é Iturama, mas [gesto indicando entre aspas] tem muita gente daqui que é de fora, longe daqui, entendeu? Vem por aí, aí já começa a fazer amizade, já se acampa ou, vamos falar assim, num é o certo, mas existe ainda um erro, mas existe a compra de lote, entendeu? Aí, compra o lote, aí já é um morador, um pequeno proprietário ou consegue o lote na luta mesmo... Isso acontece muito. Só o nosso assentamento aqui, que é o mais velho, tem dez anos, que não tem gente de fora, vamos falar assim. Só os daqui mesmo. Mas a maioria aqui da região, são dez assentamentos, tem muita gente de fora. ${ }^{37}$
\end{abstract}

No período indicado, as implementações de máquinas, a quebra de relações entre pequenos agricultores, juntamente com a dureza e a exploração do trabalho nos canaviais estão sugerindo conjunturas ampliadas de ação que informam diferentes experiências sociais e ativas "consciências" políticas. Por esses vieses, nos quais o trabalho e as condições materiais são determinantes para os trabalhadores, as dinâmicas de movimentação e

\footnotetext{
${ }^{37}$ Entrevista feita por Gabriel de Araújo Oliveira. Local: Campina Verde (MG). Entrevistada: Divina Catarina Borges de Almeida, presidente do Sindicato dos Trabalhadores Rurais de Campina Verde. Data: 08/06/2009. op. cit. Acervo da Pesquisa (2008-2010).
} 
mudanças nas relações de trabalho e vida criam bordas de resistências e, neste caso, de luta pela terra.

Nessas dimensões, nas quais a exploração e a expropriação do trabalho persistem há décadas (reformado por máquinas, por mudanças nas condições de pequenas propriedades, pela diminuição nas possibilidades de lida com outras "culturas" e por questões ambientais, por que não?), os trabalhadores reconstituíram vivências e relações de classe, que, ao ser experimentadas, criaram outras formas de ações, de negociações, gerando perspectivas de "consciência", ou melhor, "consciência de classe" - que, por sua vez, "são tratadas em termos culturais: encarnadas em tradições, sistemas de valores, idéias e formas institucionais", no caso, a busca por movimentos organizados. ${ }^{38}$

Não há melhores ou piores modos de formação de consciência de classe. Para Thompson:

Podemos ver uma lógica nas reações de grupos profissionais semelhantes que vivem experiências parecidas, mas não podemos predicar nenhuma lei. A consciência de classe surge da mesma forma em tempos e lugares diferentes, mas nunca exatamente da mesma forma. ${ }^{39}$

Vale acrescentar, de acordo com Thompson, que os trabalhadores experimentam não apenas ideias no âmbito do pensamento, mas, além disso, como sentimentos, normas, valores, obrigações, que são expressas em ações e também em resistências, em sentido de permanência: acentuando a existência, em certos enredos históricos, de uma "tradicional rebeldia", com meandros de permanência, de confrontação à mudança. ${ }^{40}$

Talvez a multiplicidade de experiências e perspectivas entre três sindicalistas (presidentes dos sindicados de Canápolis, Santa Juliana e Campina Verde) torne a interpretação de aumento de trabalhadores canavieiros em assentamentos e ocupações algo isolado, fenomenológico ou precipitado.

Mas essas informações chegam de outros meios, até mesmo da grande imprensa nacional, que cobre outras regiões do país. Novamente, através do jornal Folha de S. Paulo, de 16 de fevereiro de 2011, percebe-se a relação desses sujeitos com a reforma agrária:

Desempregados pela mecanização, ex-cortadores de cana ingressam em luta pela terra. Desde 2007, foram fechados no estado cerca de 40 mil postos de trabalho no corte da cana. José Rainha Júnior confirma que os ex-cortadores têm fortalecido os movimentos sociais. Ele estima que entre os 6 mil militantes que participaram das 42 ocupações de janeiro deste ano, pelo menos um terço era composto de

\footnotetext{
${ }^{38}$ THOMPSON, E. P. Introdução. A formação da classe operária inglesa: a árvore da liberdade. Rio de Janeiro: Paz e Terra, 1987, p. 10.

39 Ibidem. p. 10.

${ }^{40}$ Nos referimos às discussões iniciais de THOMPSON, E. P. Costumes em comum: estudos sobre a cultura popular tradicional. São Paulo: Companhia das Letras, 1998, p. 19.
} 
egressos do setor sucroenergético. "A tecnologia chegou, as máquinas desempregaram muita gente no corte de cana", conta Rainha. ${ }^{41}$

Nem todos, obviamente, partiram para a luta pela terra:

Existem ainda os trabalhadores que têm tentado conseguir um lote de terra por meio do crédito rural. O presidente do Sindicato de Trabalhadores Rurais de Regente Feijó, Marcelino Sotocorno, disse que apesar dos problemas burocráticos, essa tem sido a opção dos que estão desiludidos com os rumos da reforma agrária. "É uma forma de o pessoal ter, pelo menos, o lugarzinho para trabalhar", explica. Ele lembra que ter um lote de terra, mesmo que pequeno, é uma garantia de sobrevivência. "Se ele souber plantar um pé de mandioca ou de milho, fome ele não passa". ${ }^{42}$

Para nós, a noção de que "fome eles não passam" é algo que incide sobre diferentes visões até aqui exemplificadas e que despotencializam os trabalhadores e suas ações. Mostra, entretanto, as dinâmicas vividas por esses trabalhadores que se aventuram, viajam, vivem a exploração, mas criam alternativas ${ }^{43}$ e nos indicam outros horizontes de ações políticas, outros rumos para outras Histórias.

Resta-nos melhor compreendê-los.

Recebido em 10/05/2012

Aceito para publicação em 15/06/2012

\footnotetext{
${ }^{41}$ MELLO, Daniel. Desempregados pela mecanização, ex-cortadores de cana ingressam em luta pela terra. Folha de S. Paulo. Disponível em <http://noticias.uol.com.br/cotidiano/2011/02/16/desempregados-pelamecanizacao-ex-cortadores-de-cana-ingressam-em-luta-pela-terra.jhtm>. Acesso em 16/02/2011.

42 Ibidem.
} 